\title{
Herbal or modern methods of contraception! choice is yours
}

\author{
Amrendra Kumar Anand ${ }^{1 *}$, Vinod Prasad ${ }^{1}$, Mansur Alam $^{2}$ \\ ${ }^{1}$ Department of Botany, ${ }^{2}$ Department of Chemistry, B. N. College, Patna University, Patna-04, Bihar, India
}

Received: 18 May 2015

Accepted: 06 June 2015

\section{*Correspondence:}

Dr. Amrendra Kumar Anand,

E-mail: anand.ak1510@gmail.com

Copyright: (c) the author(s), publisher and licensee Medip Academy. This is an open-access article distributed under the terms of the Creative Commons Attribution Non-Commercial License, which permits unrestricted non-commercial use, distribution, and reproduction in any medium, provided the original work is properly cited.

\begin{abstract}
Contraception generally means prevention of pregnancy. There are a variety of methods ranging from natural to scientific available in accordance to its nature of use. Some methods provide short term birth control facility whereas some other provides permanent or long term birth control facility. But all the methods have some advantages and disadvantages associated with them. For example, male condoms which is made of latex, is $97 \%$ effective if used properly though some people may have allergic reaction to latex. Oral contraceptives are also widely used but it causes heart attacks, cancer, and depression among pills user women. Herbal contraception offer alternate ways for women to avoid pregnancy and it is also free from any side effects but the reliability of herbal contraceptive remains uncertain.
\end{abstract}

Keywords: Contraception, Herbal contraceptive, Pregnancy, Birth control.

\section{INTRODUCTION}

India is among the first countries which launch the family planning programme very early in 1952. The most probable future view was that the all-round development will be achieved only when the population will remain under control. But till the date goal is far away. The Indian population growing with an alarming rate of $1.28 \%$ per year, ${ }^{1}$ may over- take China by $2030 .^{2}$ The importance of small family is known to all from the beginning of civilization. The Rigvedic incantation ${ }^{3}$ that $a$ man with many children succumbs to miseries is probably the oldest message against large family. It is our cultural belief that to have one enlightened son is better than to have hundreds of illiterate sons. The history of birth control measures is as old as our civilization.

Contraception generally means prevention of pregnancy. Various methods of contraception are in practice today. All the methods have some advantages and disadvantages associated with them. Also, no any single method is suitable for all, and hence before choosing any one, people have to take expert advice.

\section{METHODS OF CONTRACEPTION}

When a mature egg released from the ovary get fused with the viable sperm in fallopian tube, and later implanted with the wall of uterus, the female is said to be pregnant. The uterus provide appropriate environment for the development of the foetus. The purpose of birth control measures is prevention or termination of unintended pregnancy. The target of contraceptive means is either to prevent release of sperms in the reproductive tract of the female (i.e., ejaculation), release of egg from the ovary (i.e., ovulation), union of egg and sperm in the oviduct (i.e., fertilization), attachment of embryo to the uterus wall (i.e., implantation) or termination of the developing embryo from the uterus (i.e., abortion).

Contraception can be achieved through various methods which may be grouped into following categories: natural, physical, chemical (hormonal and non-hormonal) and surgical. The natural methods of birth control considered 'natural' because they don't rely on use of hormones or any devices. Instead, they require that a man and woman do not have sexual intercourse during the fertile period 
(middle period of menstrual cycle) of the female. The fertile period can be calculated by the inspection of change in quality and quantity of cervical mucus, recording of basal body temperature, calculating fertile period with the help of calendar as well as by calculating when a women ovulate each month. The level of oestrogen in blood is on peak just before the ovulation and in response to this change happens with the cervical mucus. As the egg gets ready to release, more mucus is produced which is thin, slippery and transparent and often white or yellow in colour. This period is not safe for unprotected sex. After this, the time before starting of next period, less sticky, scant and darker mucus is produced in very less amount.In these 'dry' days pregnancy isn't likely to happen.

In basal body temperature method, a women record her temperature daily when she is relaxed and rested usually after morning wake-up. Before ovulation the 'baseline' temperature is typically in between $96-98^{\circ} \mathrm{F}$, but after ovulation temperature will rise usually less than $1^{\circ} \mathrm{F}$. Such a small change is difficult to detect. Progesterone released by the corpus luteum after ovulation cause the increase in temperature which will remain raised until the next period. ${ }^{4} \mathrm{~A}$ woman can predict her fertile days by tracking and recording the basal body temperature for a few months. Women are likely to get pregnant 2-3 days before temperature peaks and day after that. So they should be aware before sexual relationship. ${ }^{5}$

In calendar rhythm method, women avoid pregnancy by calculating probable fertile period on calendar. To get the best result there is need to track and record how long the menstrual cycle extended for at least 08 months. Calculation of first and last day of fertile period in which a woman is more likely to get pregnant can be done as: subtract 18 days from the total days of shortest cycle, take that number and count ahead from the very first day of next period. It will represent the first day of fertile period. Similarly, subtract 11 days from the total days of longest cycle, take the number and count ahead from the very first day of next cycle. It will represent the last day of fertile period. For example, if the shortest and longest period is 27 days and 29 days respectively, the first and last day of fertile period will be $09^{\text {th }}(27-18=09)$ day and $18^{\text {th }}(29$ $11=18$ ) day of the next cycle. If the period starts on $2^{\text {nd }}$ day of the month, the fertile period will be $10^{\text {th }}$ to $19^{\text {th }}$ day of the month. ${ }^{5}$

Breastfeeding also induces infertility i.e. lactational amenorrhea. It delays the resumption of normal ovarian cycles by disrupting the pattern of pulsatile release of $\mathrm{GnRH}$ from the hypothalamus and hence Leutinizing Hormone (LH) from the pituitary. The plasma concentrations of Follicle Stimulating Hormone (FSH) during lactation are sufficient to induce follicle growth, but the inadequate pulsatile LH signal results in reduced estradiol production by these follicles. When follicle growth and estradiol secretion does increase to normal, the sucking stimulus prevents the generation of pre-ovulatory LH surge and follicle either fail to rupture, or becomes atretic or cystic. Only when the sucking stimulus decline sufficiently to allow generation of a normal pre-ovulatory LH surge to occur will ovulation takes place with the formation of a corpus luteum of variable normality. ${ }^{6}$

Two practices- withdrawal or coitus interruptus and abstinence- also control unintended pregnancy. In the former, man withdraws his penis from the vagina of the woman before ejaculation so the sperm doesn't enter woman's vagina. Theoretically it is very simple but practically very difficult because it needs self- control and precise timing for withdrawal. Also, a small amount of sperm releases before actual ejaculation. The abstinence from any type of sexual intercourse with member of opposite sex is the best and $100 \%$ effective way to control pregnancy. It also protects the partners from sexually transmitted diseases STDs. In physical method contraception is achieved through the use of male and female condoms, cervical cap with spermicide, diaphragm etc. This method also prevents the spreading of sexually transmitted diseases (STDs).

\section{Hormonal methods}

Hormonal method of birth control is most prevalent today. Steroidal hormonal preparation in the form of oral contraceptive pills, contraceptive rings, depo- injectable or intrauterine devices (IUDs) help in birth control.

\section{Oral contraceptive pills (OCPs)}

The contraceptive pills are most effective method of contraception. There are three categories of OCPs: Combined Oral Contraceptive Pills (COCP), ProgestineOnly Pills (POPs) or, 'Minipills' and Emergency Contraceptive Pill (ECPs) or 'Morning-after Pills'. The oral contraceptive pill contains derivatives of two steroidal hormones: oestrogen and progesterone.To make them 'oral', the oestrogen and progesterone are used in the form of their derivatives because in their native form they are metabolized in gastrointestinal tract and liver ${ }^{7}$.The estradiol, which is the most potent and principal oestrogen secreted by ovary, is used in synthetic form as mestranol or ethinyl estradiol. Some synthetic forms of progestin which are used in contraceptives are norethidrone, norethindrone acetate, norgestrel, levenogestrel, ethinodiol diacetate etc. ${ }^{7}$ The combined oral contraceptive (COCs) pill contains both the hormonal derivatives whereas theprogestin- only pills (POPs) or 'Minipills' contain only progestin. There are three types of ECPs: combined ECPs containing oestrogen and progestin, progestin-only ECPs, and ECPs containing an antiprogestin- mifepristone or ulipristal acetate. ${ }^{8}$ All the combination pills contain oestrogen typically ethinyl estradiol and one of the eight kinds of progestin. They have variable effects on the female side.

\section{Mechanism of action of contraceptive pills}

After the onset of puberty, hormones of hypothalamus and anterior pituitary stimulate the secretion of sex 
steroids- oestrogen and progesterone. These hormones are responsible for maturation of reproductive organs, development of secondary sexual characters and regulation of menstrual cycle and maintenance of pregnancy. ${ }^{9}$ These hormones through negative feedback effect prevent secretion of FSH and LH from the anterior pituitary, and indirectly affects the maturation of Graafian follicles and releasing of egg. This is the basis of birth control through hormonal contraceptive pills, vaginal rings, injectable or hormone based methods.

In the menstrual cycle, fluctuation of hormones control ovulation. Instead of this cyclical fluctuation, the pill provides a constant level of these hormones in blood. Due to this, the feedback mechanism of pituitary is blocked which in turn blocks the ovaries from producing oestrogen in the usual pattern. Without the oestrogen peak, ovulation can't occur and without which pregnancy can't occur. Progesterone alters the mucus of the cervix, making it impassible by sperm and also slows the transport of the egg in the fallopian tube and interferes with implantation. ${ }^{4}$

\section{Side effects of hormonal contraceptive pills}

Although taking hormone- based contraceptive- measures is a fast and forward way, but its short and long term complications should be carefully considered. Before choosing any birth control measure, some factors must be kept in mind.

a) Potential short and long term side-effects.

b) Probable effects on future children.

c) Degree of effectiveness and chance of getting pregnant.

d) Chance of reversal.

e) Protection from STDs.

Although, various measures have been taken to minimize the side effects associated with pills, but still many short and long term adverse effects remain with these pills. It is now obvious that there can't be an ideal contraceptive, suitable for everyone ${ }^{10}$. Before starting any pill, some factors must be carefully considered like:

- Age of the female

- Health status of the female,

- Habit of the female (eg. Smoking, drinking etc.),

- $\quad$ Dose and composition of the pill.

Even considering the above factors, if any of the following sign-ACHES (abdominal pain, chest pain, $\boldsymbol{h}$ eadaches, $\boldsymbol{e y e}$ problem and severe leg pain), the user must consult the expert.

The most common side effects especially in new users are breakthrough bleeding (BTB) and amenorrhea. ${ }^{11}$ BTB is any of various forms of vaginal bleeding usually during the mid-way of menstrual cycle. It is likely due to hormonal fluctuations. Oestrogen (and also FSH, LH and progesterone) regulates the shedding of endometrium. The excessive oestrogen level provided by contraceptives, cause pre-period bleeding. Smokers are prone to BTB. Its chance also increases when a women changes one particular contraceptive to other. Amenorrhea is the absence of menstrual period in a woman of reproductive age. Hormonal contraceptives especially minipills and high dose Depo-Provera commonly induces this side effect. The other common side effects are nausea, vomiting, headache, breast tenderness, swelling of ankle or feet etc.

Use of hormonal contraceptive has some major sideeffects. It increases the risk of thromboembolism (including deep vein thrombosis and pulmonary embolism) which may cause permanent disability or death. $^{12}$ Theriskof cardiovascular disease is higher in COCs- user than non-user especially after 35 year of age. $^{13}$ This risk again increases when women have smoking habit and continuously using the pills. ${ }^{14}$ According to a report of IARC (2007), COCs increase the risk of cancer of breast, cervix and liver. Cervical cancer risk increases in women who get infected with papilloma virus. $^{15}$

Pills cause depression. Serotonin, a neurotransmitter, has been linked to depression. High levels of oestrogen and progestin increase the concentration of a brain enzyme that reduces the level of serotonin and cause depression. ${ }^{16}$ The condition becomesworst when an already depressed woman uses only progestin pill. ${ }^{17}$ Use of pill also has connection with hypertension. Bradykinin, a peptide, causes blood vessels to dilate (enlarge), and therefore lowers blood pressure. Progestin of the pill can increase the levels of an enzyme aminopeptidase-P which break down the bradykinin and thereby increase the risk of hypertension. ${ }^{18}$ Excess oestrogen from pills appears to increase cholesterol levels in bile and decrease gall bladder movement which can lead to gallstones (NDDIC, 2007).

\section{Herbal contraception:}

Since ancient times, mankind has belief on plants to cure diseases and physical sufferings. Because of its cultural acceptability, better compatibility with human body, lesser side effects and effectiveness traditional medicines now have worldwide acceptance. More than 35000 plant species are being used in various human cultures, around the world for medicinal purposes. ${ }^{19}$ Nearly $80 \%$ of the world population relies on traditional medicines for primary health care, most of which involve the use of plant extract. ${ }^{20}$ Herbal medication, also called 'Botanical medicines' or 'Phytomedicines', is the practice of using one or more parts of a plant (its flower, fruits, seeds, roots, leaves, bark) to relieve physical and psychological problems. These plant- based remedies prevent diseases, improve overall health and vitality. Herbal preparations have also been used since time immemorial for their effect upon reproductive health particularly for 
suppressing fertility, regularizing menstrual cycle, relieving dysmenorrhea, treating enlarged prostate, menopausal symptoms, breast pain and labour- pain during and after childbirth. ${ }^{21}$

Herbal contraceptives offer alternate ways for women who have some health problems, orlack of access to modern contraceptive options particularly women living in the rural areas in developing nations with very high population like India, China, and Bangladesh. Herbal contraceptives and abortifacients are plants and plant based preparation used for birth control or in the prevention of pregnancy and for premature expulsion of a foetus from the womb. ${ }^{22}$ These herbs are variable in their action. They may act through rapid expulsion of the fertilized ova from the fallopian tube, inhibition of implantation due to disturbance of oestrogenprogesterone balance, foetal abortion perhaps due to lack of supply of nutrients to uterus and the embryo and also on the male side through affecting sperm count, motility and viability ${ }^{23-25}$ (Ciganda \& Laborde 2003; Kauntiz \& Benrubi 1998; Noumi \&Tchakonang 2001). Each herb may have one or more than one birth controlling activity. For instance, Curcuma longa (H. Haldi) inhibits sperm motility and prevents implantation, Embelica ribes $(\mathrm{H}$. Vidanga) have antifertility and anti-oestrogenic action, Jatropha curcus (H. Jangali arandi) decrease sperm motility, sperm count and also have abortifacient action. The use of herbal contraceptives is plant-wise variable. Some herbal preparation need to be taken daily (i.e, daily herbal contraceptive) to maintain the contraceptive effect. They need a period of time to establish their effectiveness and a barrier method should be employed; examples are wild Yam (Dioscorea villosa) and Neem (Azadirachta indica). Many other plants act as implantation-preventor and are taken only during fertile period.They make difficult for the fertilized egg to implant or maintain its grip on the uterine wall ${ }^{9}$. Pradhan et al. in 2012 enlisted 133 indigenous medicinal plants with various antifertility effects. ${ }^{7}$ So it is important to have some idea of how they are used or could be used. Plants used in birth control preparation contain various bioactive principles which interfere with fertility. Now it is scientifically proved fact that the active constituents of various plants possess birth controlling properties.

Why herbal contraceptives lagging behind the modern pill? This is an obvious question that comes in our mind. Several factors are responsible for this. One major factor is that, it is impossible for us to say how effective they are as the information are remain scarce and fragmented, and transmitted orally among ethnic people. The modelanimal based scientific description of very little number of plants is available till now. Also, very little is known about long term side effects associated with these herbal preparations. Although, many plants have birth controlling bioactive compound, but standardization of these compounds as birth controlling drugs remains a challenging task. The concentration and potential of active constituents of a plant is variable according to the variation in season and bio-geographical regions. Hence, the reliability of herbal contraceptive remains uncertain and people do not show much interest in this 'ecofriendly' birth control option.

Table 1: Kind of progestin, their generation and potential effects.

\begin{tabular}{|c|c|c|c|}
\hline $\begin{array}{l}\text { Sl. } \\
\text { No. }\end{array}$ & Kind of Progestin & Generation & Effects \\
\hline 1. & Northindrone & $1^{\text {st }}$ & $\begin{array}{l}\text { Low progestational and slight oestrogenic effect. In low dose } \\
\text { improve lipid profile by raising HDL and lowering LDL. }\end{array}$ \\
\hline 2. & Northindrone Acetate & $1^{\text {st }}$ & Low progestational and slight oestrogenic effect. \\
\hline 3. & Ethynodiol Diacetate & $1^{\text {st }}$ & $\begin{array}{l}\text { Medium progestational effect, minor oestrogenic effect and } \\
\text { little androgenic effect. Associated with mid-cycle BTB and } \\
\text { spotting but with higher dose of oestrogen, no such side effects. }\end{array}$ \\
\hline 4. & Levonogestrel & $2^{\text {nd }}$ & $\begin{array}{l}\text { High progestational and androgenic effect. Negatively affect } \\
\text { serum lipoprotein. }\end{array}$ \\
\hline 5. & $\begin{array}{l}\text { Norgestrel } \\
\text { Mixture of inactive } \\
\text { (dextro-norgestrel) \& } \\
\text { active levonogestrel. }\end{array}$ & $2^{\text {nd }}$ & $\begin{array}{l}\text { High progestetational and strong antioestrogenic effect as well } \\
\text { as high androgenic effect. May cause LDL cholesterol to be } \\
\text { increased and allowing HDL cholesterol to be lower. }\end{array}$ \\
\hline 6. & Desogestrel & $3^{\text {rd }}$ & $\begin{array}{l}\text { High progestational selectivity, minimizing androgenic effects } \\
\text { and oestrogenic activity. }\end{array}$ \\
\hline 7. & Norgestimate & $3^{\mathrm{rd}}$ & $\begin{array}{l}\text { High progestational and slight oestrogenic effect. Minimal } \\
\text { effect on serum lipoprotein and on carbohydrate metabolism. } \\
\text { Helpful in lowering side-effects such as nausea and vomiting. }\end{array}$ \\
\hline 8. & $\begin{array}{l}\text { Drospirenone } \\
\text { (Progestin derived } \\
\text { from } 17 \mathrm{a}- \\
\text { Spirolactoneis) }\end{array}$ & $4^{\text {th }}$ & $\begin{array}{l}\text { Potent progestogenic, low androgenic activity helps to suppress } \\
\text { the secretion of the hormone that regulates the body's water and } \\
\text { electrolyte. Causes higher K level, so women with kidney, liver } \\
\text { or adrenal disease shouldn't use. }\end{array}$ \\
\hline
\end{tabular}


Table 2: Some common plants with their birth control activity.

\begin{tabular}{|c|c|c|c|c|c|c|}
\hline \multicolumn{7}{|c|}{ A. Effects on Female Side: } \\
\hline $\begin{array}{l}\text { Sl. } \\
\text { No }\end{array}$ & Action & Botanical name & $\begin{array}{l}\text { Common } \\
\text { name }\end{array}$ & Family & Parts used & References \\
\hline \multirow{3}{*}{1.} & \multirow{3}{*}{$\begin{array}{l}\text { Implantation } \\
\text { Preventer }\end{array}$} & Adhatoda vasica & $\begin{array}{l}\text { Aduss, } \\
\text { Arusa }\end{array}$ & Acanthaceae & Leaves & 6 \\
\hline & & Alium cepa & Onion & Liliaceae & Bulb & 6 \\
\hline & & Cassia fistula & Amaltas & Caesalpiniaceae & Pods, Seeds & 10,2 \\
\hline \multirow{3}{*}{2.} & \multirow{3}{*}{ Abortification } & Abrus precatorius & $\begin{array}{l}\text { Ratti, } \\
\text { Gunchi, } \\
\text { Gunja }\end{array}$ & Fabaceae & Seeds & $10,5,2,9,7$ \\
\hline & & Jatropha curcas & $\begin{array}{l}\text { Jamal ghota, } \\
\text { Ratanjot }\end{array}$ & Euphorbiaceae. & Fruits & 3 \\
\hline & & Plantago ovata. & Isabgol & Plantaginaceae & Seeds & 10,2 \\
\hline \multirow{3}{*}{3.} & \multirow{3}{*}{ Contraception } & Bacopa monnieri & Brahmi & $\begin{array}{l}\text { Scrophulariacea } \\
\text { e }\end{array}$ & Plant & 10 \\
\hline & & Aegel marmelos & Bel & Rutaceae & Leaf & $10,2,9$ \\
\hline & & Piper nigrum & Black pepper & Piperaceae & Fruit powder & 3 \\
\hline \multirow[t]{3}{*}{4.} & $\begin{array}{l}\text { Antioestrogen } \\
\text { ic }\end{array}$ & Acalypha indica & $\begin{array}{l}\text { Kuppi, } \\
\text { Kuppikhokh } \\
\text { ali }\end{array}$ & Euphorbiaceae & Whole plant & 5,2 \\
\hline & & Croton roxburghii & Banmirchi & Euphorbiaceae & Bark & 10 \\
\hline & & Nelumbo nucifera & Lotus & Nymphiaceae & Seeds & 6,11 \\
\hline \multirow[t]{3}{*}{5.} & Antiovulatory & Aspilia Africana & $\begin{array}{l}\text { Haemorrhag } \\
\text { e plant }\end{array}$ & Asteraceae & Leaves & 10 \\
\hline & & $\begin{array}{l}\text { Butea } \\
\text { monosperma }\end{array}$ & Palas & Papilionaceae & Seeds & $1,12,8,7$ \\
\hline & & Ficus religiosa & Peepal & Mosaceae & Seeds & 6 \\
\hline B. & Effects on $M$ & ale Side: & & & & \\
\hline \multirow{3}{*}{1.} & \multirow{3}{*}{ Spermicidal } & Aloe vera & $\begin{array}{l}\text { Ghritakumar } \\
\text { i }\end{array}$ & Liliaceae & Latex & 11 \\
\hline & & $\begin{array}{l}\text { Clerodendrum } \\
\text { serratum }\end{array}$ & $\begin{array}{l}\text { Babhneti, } \\
\text { Bharangi }\end{array}$ & Verbenaceae & $\begin{array}{l}\text { Whole plant } \\
\text { except root }\end{array}$ & 6 \\
\hline & & Terminillia bellirica & $\begin{array}{l}\text { Bahera, } \\
\text { Bahuvirya }\end{array}$ & $\begin{array}{l}\text { Combretacea } \\
\text { e }\end{array}$ & Fruits & 3,2 \\
\hline \multirow{3}{*}{2.} & \multirow{3}{*}{$\begin{array}{l}\text { Reduce sperm } \\
\text { count \& sperm } \\
\text { motility }\end{array}$} & Tinospora cordifolia & $\begin{array}{l}\text { Amrita, } \\
\text { Giloy, } \\
\text { Guduchi }\end{array}$ & $\begin{array}{l}\text { Menisperma } \\
\text { ceae }\end{array}$ & Stem & 4,7 \\
\hline & & Ocimum sanctum & $\begin{array}{l}\text { Tulsi, } \\
\text { Ocimum }\end{array}$ & Labiatae & Leaves & 10,2 \\
\hline & & Lobelia inflata & $\begin{array}{l}\text { Pokeweed, } \\
\text { Indian } \\
\text { tobacco }\end{array}$ & Lobeliaceae & Stem & 7 \\
\hline \multirow{3}{*}{3.} & \multirow{3}{*}{$\begin{array}{l}\text { Inhibit } \\
\text { spermato- } \\
\text { genesis }\end{array}$} & Lawsonia intermis & $\begin{array}{l}\text { Henna, } \\
\text { Mehandi }\end{array}$ & Lythraceae & Flower & 2 \\
\hline & & $\begin{array}{l}\text { Hibiscus rosa- } \\
\text { sinensis }\end{array}$ & China rose & Malvaceae & Flower & 3 \\
\hline & & Randia dumetorum & Mainaphal & Rubiaceae & Fruit & 10,12 \\
\hline
\end{tabular}

1. Shah GM, Khan MA, Ahmad M, Zafar M, and Khan AA. Observations on antifertility and abortifacient herbal drugs. African Journal of biotechnology. 2009;8(9):1959-64.

2. Kaur R, Sharma A, Kumar R, Kharb R. Rising trends towards herbal contraceptives. Journal of Natural products and Plant Resource. 2011;1(14):5-12.

3. Pathak AK, Mallurwar VR, Kondalkar AK, Soni S. A Review of Plants with Antifertility Activity. Nig. J Nat Prod and Medicine. 2005;09:4-10.

4. Ahmad S, Jamal Y, Mannan A. Review of Some Medicinal Plants with Anti-fertility Activities. Unani Res. $2011 ; 1(2): 24-8$. 
5. Kong YC, Nag KH, Wat KH, Wong A, Saxena IF, But PPH and Chang HT. Yuechukene, a novel antiimplantation indol alkaloids from Murrayapaniculata. Planta Medica. 1985;51(2):304-7.

6. Pokharkar RD, Saraswat RK, Kotkar S. Survey of Plants having antifertility activity from Western Ghat area of Maharastra state. Journal of Herbal medicine and Toxicology. 2010;4(2):71-5.

7. Kalita JC, Chakrabarty A, Tanti B. Assessment of Antifertility activity of some traditionally used plants by different ethnic communities in three districts of Assam, India. Journal of Herbal Medicine and Toxicology. 2011;5(2):65-72.

8. Shrivastava S, Dwivedi S, Dubey D, Kapoor S. Traditional Herbal Remedies from Madhya Pradesh used as Oral Contraceptives-A Field Survey. International Journal of Green Pharmacy. 2007;1(1):18-22.

9. Azmeera M, Elumalai A, Eswaraiah MC and Mathangi N. An Updated Review on Anti-fertility Plants. 2012;2(1):4-6.

10. Priya G, Sarvanan K, Renuka C. Medicinal Plants with Potential anti-fertility activity-A review of sixteen years of herbal medicine research (1994-2010). International Journal of Pharm Tech Research. 2012;4(1):481-94.

11. Gedia S, Ribadia C, Soni J, Sah N. Jain H. 'Herbal plants used as contraceptives'. Int J of Current pharmaceutical reviews and research. 2011;2(1):47-53.

12. Ravichandran V, Arunachalam G, Subramanian N, Suresh B. Contraceptive and its significance in traditional system of medicines. International journal of pharmaceutical sciences. 1998;1-21.

Table 3: Bioactive component of plants and their anti-fertility property/s.

\begin{tabular}{|lllll|}
\hline S. No & Plant & Active Constituent & Birth control property/s & References \\
\hline 1. & Epharispermum subsessile & Desmethylilisoencecalin & Antiimplantation & 1 \\
\hline 2. & Vicoa indica & Vicolid D & $\begin{array}{l}\text { Antiimplantation and } \\
\text { Abortifacient }\end{array}$ & 2 \\
\hline 3. & Aristolochia indica & Aristolic Acid & $\begin{array}{l}\text { Antiestrogenic and } \\
\text { Antiimplantation. }\end{array}$ & 3 \\
\hline 4. & Striga onobanchioides & Apigenin and Luteolin & Antiimplantation. & 4 \\
\hline
\end{tabular}

1. Agarwal SK, Verma S, Sing SS, Kumar S, Keshi G. Antifertility chomene from Blepharispermum subsessile. Fitoterapia. 1999;70:435-7.

2. Alam M, Susan, Joly S, Bhima Rao. Indian Drugs. 1988;26:337-40.

3. Anita P, Chakrbarty B. Indian J Exp Biol. 1987;16:1283-85.

4. Hiremath SP, Badami S, Hunasagatta SK, Patil SB. Europian Journal of Pharmacology. 2000;391:193-7.

\section{Intrauterine device (IUD) for birth control}

IUD is an important device of family planning. Generally it is adopted to avoid the conception for long duration of three years to ten years. The IUD is mainly meant for damaging and killing of the sperms but in adverse situation, if fertilization has taken place then it works in different manners like- it modifies the wall of uterus to prevent the implantation. ${ }^{26}$ The IUD is of two typeshormonal (levonogestrel) based and copper coiled based. Copper content of the IUD damage / kills the sperm while the hormonal IUD enhances the viscosity of the mucous modifies the uterus wall to prevent implantation and also it prevents ovulation.

There are several side effects of both types of IUDs. The copper based IUD increases the menstrual bleeding, spotting between periods and also in some cases it is expelled from the uterus to increase the risk of pregnancy. ${ }^{26}$ The hormonal IUD decreases the menstrual bleeding and also it promotes to development of ovarian cysts. In some cases its symptoms appear in the form of breast tenderness, mood swings, headache and acne and if someone has got pregnancy then it promotes miscarriage or preterm birth.

\section{SUMMARY}

The present study reveals that contraception which means prevention of pregnancy has been using for ancient period in various forms. For example, The natural methods of birth control seems to be very easy without any side effect but practically it is very difficult because it needs self control, calculation of accurate timing of fertile period etc. chemical methods (hormonal and nonhormonal) are most prevalent today but these methods have many health risks such as breakthrough bleeding (BTB), amenorrhea, nausea, breast tenderness, cardiovascular diseases etc. Herbal contraceptives offer alternative ways for such people who have some health problems or lack of access to modern contraceptive options. Although such contraceptives have more or less no side effects yet the concentration and potential of active constituents of a plant as birth controlling drugs is variable according to the variation in season and biogeographical regions and hence reliability of herbal contraceptive remains uncertain. Once the plants are 
identified then in most effective phase of its growth and also in appropriate season, their active ingredients should be isolated, identified and special emphasis should be given to standardise their dose according to the target sites. In addition to these, it should be advertise properly so that pupil can rely on the use of herbal contraceptive.

Funding: No funding sources

Conflict of interest: None declared

Ethical approval: Not required

\section{REFERENCES}

1. Population growth (annual \%), World Bank, Retrieved 20 January, 2015.

2. United Nation, 2009.

3. Rig-Veda, 1:164:32.

4. Cherniak D. A book about birth control, $3^{\text {rd }}$ edition; Montreal health press, Inc. 1984; 3-55.

5. Office of the Population Affaires; US Dept. of Health and Human Science, 200 Independence Avenue, SW Washington DC.

6. McNeilly AS, Tay CC, Glasier A. Physiological mechanism underlying lactational amenorrhea. Ann N Y Acad Sci. 1994;709:145-55.

7. Pradhan DK, Mishra MR, Mishra A, Panda AK, Behra RK, Jha S, et al. A comprehensive review of plants used ascontraceptives. IJSPR. 2012;4(1):14855 .

8. Trussel J, Raymond EG, Cleland K. Emergency Contraception: a last chance to prevent unintended pregnancy. 2014;1-33.

9. Ravichandran V, Arunachalam G, Subramanian N, Suresh B. Contraceptive and its significance in traditional system of medicines. International journal of pharmaceutical sciences. 1998;1-21.

10. Moudgal NR, Rao AJ. 'Contraception through immunization and regulation of luteal function; David Puett: Publication of United Nation Fund for Population Activities, New York, 1984; 73-79.

11. Serfaty D. Medical aspects of oral contraceptive discontinuation. Advances in Contraception. 1992;8:21.

12. Blanco-Molina Á, Monreal M. Venous thromboembolism in women taking hormonal contraceptives. Expert Review of Cardiovascular Therapy. 2010;8(2):211-5.

13. Gierisch JM, Coeytaux RR, Urrutia RP, et al. Oral contraceptive use and risk of breast, cervical, colorectal, and endometrial cancers: a systematic review. Cancer Epidemiol Biomarkers Prev. 2013;22(11):1931-43.
14. Rang HP, Dale MM, Ritter JM, Flower RJ, Henderson G. The reproductive system, Rang and Dale's pharmacology, 7th ed., Edinburgh: Elsevier/ Churchill Livingstone. 2012; 426.

15. Gierisch JM, Coeytaux RR, Urrutia RP, et al. Oral contraceptive use and risk of breast, cervical, colorectal, and endometrial cancers: a systematic review. Cancer Epidemiol Biomarkers Prev. 2013;22(11):1931-43.

16. Kulkarni J. Contraceptive Pill Linked to Depression. Monash Newsline. Retrieved 2007-10-29.

17. FFPRHC. The UK Medical Eligibility Criteria for Contraceptive Use (2005/2006) (PDF). Archived from the original on 2007-06-19. Retrieved 2007-0331.

18. La Corte ALC, Carter AM, Turner AJ, Grant PJ, Hooper NM. The bradykinin-degrading aminopeptidase $\mathrm{P}$ is increased in women taking the oral contraceptive pill. Journal of ReninAngiotensin-Aldosterone System. 2008;9(4):221.

19. Lewington A. 'Medicinal plants and plant extracts: A review of their importation into Europ.' Cambridge, UK; Traffic international, 1993.

20. Sandhya B, Thomas S, Isabel W, Shenbangarathai R. Ethnomedicinal plants used by the Valaiyan community of Piranmalai Hills (Reserved Forest), Tamil Nadu, India. A pilot study. Afr. J. Traditional Complementary Alter. 2006;3(1):101-14.

21. Williamson EM, Okpako DT, Evans FJ. Pharmacological methods in phytotherapy research. Selection, preparation and pharmacological evaluation of plant material. John Wiley and Sons, London; 1996;1:191-212.

22. Kumar D, Mishra PK. Plant based contraceptive popular among Tribals of Jharkhand. Bioscience Discovery. 2010;2(1):11-4.

23. Ciganda C, Laborde A. Herbal infusion used for induced abortion. Journal of toxicology and Clinical toxicology. 2003;41(3):235-9.

24. Kauntiz M, Benrubi GI. The good news about hormonal contraception and gynaecologic cancer. The Female Patients. 1998;23:43-51.

25. Noumi NYC, Tchakonang C. Plants used as abortifacients. Journal of ethnopharmacology. 2001;76(3):263-8.

26. Grimes DA. Intrauterine devices (IUDs).In RA Hatcher et al., eds., Contraceptive Technology, 19th ed., New York: Ardent, 2007; 117-143.

Cite this article as: Anand AK, Prasad V, Alam M. Herbal or modern methods of contraception! choice is yours. Int $\mathrm{J}$ Reprod Contracept Obstet Gynecol 2015;4:947-53. 